\title{
Evaluation of Surface Roughness of Nano-Hybrid Composite Resins Comparing One-Step Polishing Systems Versus Multi-Step Polishing Systems versus Multi-Step Polishing Systems
}

\author{
Indhira Melo ${ }^{1}$, Aman Kumar ${ }^{2}$, Pedro Henriquez Ureña ${ }^{3}$, Alberto Luis Martinez Vicente DDS ${ }^{4}$ and Klenise Paranhos ${ }^{5 *}$
} ${ }^{1}$ College of Dentistry,USA

${ }^{2}$ Touro College of Dental Medicine, USA

${ }^{3}$ Clinical Assistance Professor, Ashman Department of Periodontology and Implant Dentistry, USA

Submission: October 23, 2018; Published: October 31, 2018

*Corresponding author: KleniseParanhos, Clinical Assistance Professor at Ashman Department of Periodontology and Implant Dentistry, USA

Abstract

Aim: The purpose of this study was to compare the surface roughness of nano-hybrid composite polished by a multi-step polishing system versus one-step polishing systems.

Materials and Methods: Sixty composite specimens were prepared using two brands of nano-hybrid composites, evenly. Within the two groups, the samples were further divided into three groups for three different polishing systems. All specimens were polished following the manufacturer's instructions and then subjected to a profilometer to evaluate surface roughness.

Results: There was no difference using the same polishing system on the two different brands of nano-hybrid composites. The mean roughness scores of the composites were significantly less for the multi-step polishing kit than the one-step polishing systems.

Conclusion: Multi-step polishing system showed the lowest surface roughness values, meanwhile the one-step polishing systems showed the highest surface roughness values. When using Nano-hybrid composites, the multi-step polishing system offered the best results compared to one-step polishing systems.

\section{Introduction}

Restorative dentistry can be defined as the discipline encompassing the diagnosis, prevention, and management of diseases of the teeth. A focus of restorative dentistry is to reclaim the structure, esthetics, and function of the tooth[1,2]. Composite resins are one of the most commonly used materials in dentistry as they provide highly esthetic results, while minimizing the amount of tooth reduction needed to achieve adequate retention. There are many reasons why composites resins are favorable over other restorative materials, however filler size and shape has been key in this revolution. Many years ago, resin composites had contained macrofil particles which were durability, but it was much harder to achieve a smooth polish in the variety of packable composites[3].Whereas flowable composites, which have a smaller particle size and higher resin ratio, are much easier to polish[4-6].However, a disadvantage of flowable composite is its shrinkage, lower tensile strength, therefore faster deterioration over time. Nanofilled hybrid composites contain large macrofil particles, microfil particles, and resin which contribute to, high tensile strength, reduced shrinkage, and maintenance of its polishability [7-9]. Finishing and polishing of composite restorations is a critical step that can determine its success and survival. A smooth finish lowers bacterial accumulation in the oral cavity by reducing gingival irritation, changes in the color of the restoration and its margins, recurrent decay[10-12]. Not only does a rough surface composite influence bacterial load in the oral cavity, but it has also been shown to influence stain on restorations[13,14]. Additionally, reducing irregularities higher than 15 microns in the oral cavity are interpreted by patients who report discomfort with their restorations[14,15].Composites have various surface textures due to the polishing methods of the fillers and resin in the composites. Such techniques that influence a polish include presence of water, speed of the handpiece, and pressure of the polishing tip on the restoration[16-18].Many polishing systems claim to provide a smooth contour and finish to composite restorations, however this is dependent on the presence of abrasives in the tips. Polishing kits range from one-step to multistep systems that provide differences in the surface texture of 


\section{Global Journal of Otolaryngology}

composite resins[19-21].This investigation was performed to examine surface roughness of new nano-filled hybrid composites with different polishing systems. The study hopes to provide insight on selection of polishing system.

\section{Methods and Materials}

This study was conducted at Universidad Autónoma de Nuevo León using the Mitutoyo Surftest 211 profilometer. Every specimen was tested once, and the result was written on the data collection sheet. In total, sixty total composite specimens were prepared from two different nano-hybrid composites were prepared to be finished with 3 polishing systems. Thirty specimens were fabricated from Tetric N-Ceram (Ivoclar Vivadent), while the remaining thirty specimens were produced from Charisma Diamond (Kulze). Each composite had subsequently been divided into 3 groups for the following polishing systems: Optrapol ${ }^{\circledR}$, Enhance ${ }^{\circledR}$, and So-Flex ${ }^{\mathrm{TM}}$ disks. The specimens in the two groups were then divided into three groups of ten for each polishing system. The composite specimens were prepared using round disks with an inner dimension of $4 \times 4 \mathrm{~mm}$. First, the external and internal parts of the disk were prepared with a thin coat of vaseline. The disk was then placed over a mylar strip on top of a crystal plate. Packable composite was placed into the disk using a plastic instrument in $2 \mathrm{~mm}$ increments. The increments were then polymerized for 20 seconds each cycle, using "LED B Woodpecker" with a potency of $500 \mathrm{~mW} / \mathrm{cm}^{2}$. The last layer was cured by placement of a mylar strip and crystal plate on top, respectively. The crystal plates and mylar strip were removed and the composite specimens were then cured from the top and bottom sides, for a final time.

Once the specimens were cured, the excess composite on the top and bottom surfaces was finished using a twelve-fluted finishing carbide bur for thirty seconds, at 40,000 rpm using a high-speed handpiece; NSK FPB-Y with 12 fluted bur. The specimens were finished with a high-speed hand-piece in one direction (from left to right), with water irrigation of $43 \mathrm{~mL}$ during the polishing time.The tips from the Optrapol® polishing system were placed in the low speed hand-piece at 8,000 rpm in a clock-wise direction. The polishing was initiated with light rotatory movements under moderate pressure in one direction, for 40 seconds using water. The silicone tips were changed once for every six specimens polished. Finally, they were washed and dried using an air/water syringe for 10 seconds. Every specimen was finished and polished following the manufacturer's instructions by the same person.Silicone tips from the Enhance $₫$ polishing system were used to polish the composite samples at a low-speed under moderate pressure, at 8,000 rpm in a clockwise direction in a uniform direction. The procedure occurred for two cycles of 20 seconds in circular movements, for a total of 40 seconds.Each silicone bur was changed once for every two polished specimens. Lastly, $5 \mathrm{~mm}$ of Prisma Gloss $囚$ diamond paste applied to each with a felt disk onto the composite specimens, using a low speed in a clockwise direction.Specimens polished using Sof-Lex ${ }^{\mathrm{TM}}$ were first finished with the coarse disk, using a slow speed at 8,000 rpm, using light pressure in a clockwise direction for 20 seconds, as instructed by the manufacturer. After polishing each disk, the specimens were washed and dried with a chair-side air/water syringe for 10 seconds. The polishing procedure was continued with the medium coarse, fine, and super fine disks.Each group of composites was then measured for surface roughness ( $\mathrm{Ra}$ ) for each of the polishing systems.

\section{Results}

Following polishing an analysis of surface roughness was measure for each polishing system and their respective nanohybrid composites (Tables 1-3). A graph was generated to display the mean results of the polishing systems (Figure 1). The following observations were made:

I. There was no significant difference could be made using the same polishing system, on the different nanohybrid composites.

II. Further analysis by roughness of each finished surface revealed significantly lower values (Mean: 0.18 and 0.23 for Tetric N Ceram ${ }^{\circledR}$ and Charisma Diamond $\AA$, respectively) for Sof-Lex ${ }^{\mathrm{TM}}$, across both composites.

Table 1: Surface roughness of Tetric N Ceram $®$ after polishing with by Optrapol $\circledast$, Enhance ${ }^{\circledR}$, and So-Flex ${ }^{\mathrm{TM}}$.

\begin{tabular}{|c|c|c|c|}
\hline Specimen & Optrapol ${ }^{\circledR}$ (Ra) & Enhance ${ }^{\circledR}$ (RA) & So-Flex $^{\text {TM }}$ (RA) \\
\hline 1 & 0.41 & 0.73 & 0.29 \\
\hline 2 & 0.47 & 0.74 & 0.13 \\
\hline 3 & 0.69 & 0.46 & 0.11 \\
\hline 4 & 0.57 & 0.53 & 0.14 \\
\hline 5 & 0.23 & 0.86 & 0.28 \\
\hline 6 & 0.48 & 0.59 & 0.21 \\
\hline 7 & 0.38 & 0.64 & 0.13 \\
\hline 8 & 0.38 & 0.48 & 0.14 \\
\hline 9 & 0.4 & 0.31 & 0.23 \\
\hline 10 & 0.18 & 0.51 & 0.18 \\
\hline
\end{tabular}

Table 2: Surface roughness of Charisma Diamond® after polishing with by Optrapol $\circledast$, Enhance ${ }^{\circledR}$, and So-Flex ${ }^{\mathrm{TM}}$.

\begin{tabular}{|c|c|c|c|}
\hline Specimen & Optrapol ${ }^{\circledR}(\mathrm{Ra})$ & Enhance $^{\circledR}(\mathrm{RA})$ & So-Flex $^{\mathrm{TM}}$ (RA) \\
\hline 1 & 0.42 & 0.47 & 0.11 \\
\hline 2 & 0.32 & 0.25 & 0.14 \\
\hline 3 & 0.51 & 1.14 & 0.25 \\
\hline 4 & 0.59 & 0.4 & 0.17 \\
\hline 5 & 0.62 & 0.43 & 0.18 \\
\hline 6 & 0.38 & 0.45 & 0.28 \\
\hline 7 & 0.42 & 0.9 & 0.38 \\
\hline 8 & 0.38 & 0.3 & 0.18 \\
\hline 9 & 0.46 & 5.3 & 0.1 \\
\hline 10 & 0.28 & 0.43 & 0.08 \\
\hline
\end{tabular}


Table 3: Mean roughness of the Tetric $N$ Ceram $®$ and Charisma Diamond $\AA$ following polishing by Optrapol $\circledast$, Enhance $®$, So-Flex ${ }^{\mathrm{TM}}$

\begin{tabular}{|c|c|c|}
\hline Polishing System & $\begin{array}{c}\text { Tetric N Ceram } ® \\
\text { (RA) }\end{array}$ & $\begin{array}{c}\text { Charisma } \\
\text { Diamond® (RA) }\end{array}$ \\
\hline Optrapol $®$ & 0.41 & 0.43 \\
\hline Enhance $\AA$ & 0.58 & 0.45 \\
\hline So-Flex $^{\mathrm{TM}}$ & 0.18 & 0.23 \\
\hline
\end{tabular}

So-Flex ${ }^{\mathrm{TM}}$ shows a range from 0.11-0.29 $\mu \mathrm{m}$, the polishing system Enhance ${ }^{\circledR}$ showed a range of $0.31-0.74 \mu \mathrm{m}$, while Optrapol@ showed a range of $0.18-0.69 \mu \mathrm{m}$ using Tetric $\mathrm{N}$ Ceram ${ }^{\circledR}$. So-Flex ${ }^{\mathrm{TM}}$ demonstrated the lowest roughness value of the three polishing systems.So-Flex ${ }^{\mathrm{TM}}$ shows a range from 0.08 $0.38 \mu \mathrm{m}$, the polishing system Enhance ${ }^{\circledR}$ range from $0.25-0.47$ $\mu \mathrm{m}$, while Optrapol ${ }^{\circledR}$ displays a range of $0.28-0.62 \mu \mathrm{m}$ using Charisma Diamond ${ }^{\circledR}$. So-Flex ${ }^{\mathrm{TM}}$ has a lower roughness value of the three polishing systems.

\section{Discussion}

The longevity and quality of composite restorations are greatly influenced by finished surfaces of the composite itself. As a result, many manufacturers are constantly modifying their composite and polishing systems in an attempt to simplify the process and reduce working time.The findings of this investigation show that Enhance ${ }^{\circledR}$ one-step polishing system has the lowest polishing capacity of the systems studied. This system's polishing capacity depends on the pressure applied to the composite restoration during polishing. This result differs from a 2007 study by Rodríguez Abreu y col which states that the Enhance ${ }^{\circledR}$ one-step polishing system has a better polishing capacity than the multi-step polishing system Sof-Lex ${ }^{\text {TM }}$ [21].The values of specimen numbers 3 and 9 were eliminated from the media because these specimens presented higher values (Table 3).This was due to a depression in the composite that affected the value of the reading. For Optrapol ${ }^{\circledR}$ (both Tetric N Ceram ${ }^{\circledR}$ and Charisma Diamond $(\mathbb{R})$.This study also demonstrates that the Optrapol ${ }^{\circledR}$ one-step polishing system has a better polishing capacity than Enhance $\AA$. The difference could be attributed to the fact that they differ in their abrasives; Optrapol ${ }^{\circledR}$ contains diamond abrasives which are less flexible, a characteristic that allow them to cut more evenly than Enhance ${ }^{\circledR}$. Whereas, Enhance ${ }^{\circledR}$ is composed of aluminum oxide-silicone dioxide[10,22,23].The results obtained are similar to the study done by Mustafa R. y Al-Khafaji in 2013[10].The system with the best polishing capacity in this study is the multi-step polishing system. Other studies by Caramori Rodríguez y col. (2013) and Buhler Borges A. y col.(2004)[11,19]showed similar results. The Sof-Lex ${ }^{\text {TM }}$ disk is composed of aluminum oxide particles. Additionally, the disks range from coarse to super fine, allowing a uniform surface[24].Numerous studies have found that multistep polishing systems are superior to single-step polishing systems. Of these multi-step systems, many references Sof-Lex ${ }^{\mathrm{TM}}$ as the best multi-step polishing system.

\section{Conclusion}

The advantage of the one-step polishing systems is the minimized working time. The Optrapol® one-step polishing system has a better polishing capacity than Enhance ${ }^{\circledR}$ onestep polishing system. The diamond particles in the Optrapol ${ }^{\circledR}$ allow for a more homogenous polish therefore, smoother surface. However, this investigation has found that the multistep polishing systems have a lower roughness value, indicating that they have higher polishing capacity. The best option for polishing nano-hybrid composites is the Sof-Lex ${ }^{\mathrm{TM}}$ multi-step polishing system.

\section{References}

1. Barrancos Mooney J (2006) Operatoria Dental: Integraciónclínica. ( $4^{\text {th }}$ edn), Buenos Aires: MedicaPanamericanca, Argentina.

2. Conciencao NE (2008)OdontologiaRestauradora: Salud y Estetica. $\left(2^{\text {nd }} e d n\right)$, Buenos Aires: MedicaPanamericana, Argentina.

3. Van Noort R (1983) Controversial Aspects of Composite Resin Restorative Materials. Br Dent J. 155(11):380-385.

4. Giménez FC, Borras AV (2000)Tecnología de Los MaterialesDentales. Editorial de la UPV. Valencia, Spain.

5. Giménez FC (2004)Tecnologia de Materiales. $\left(10^{\text {th }}\right.$ edn),Editorial de la UPV. Valencia, Spain.

6. SteenbekerO(2010)PrincipiosyBasesdelosBiomaterialesenOperatoria Dental Estética y Adhesiva. Editorial Ripano,Madrid, Spain.

7. Keith HS Chan, Yanjie Mai, Harry Kim, Keith CT Tong, Desmond Ng, et al. (2010)Review: Resin Composite Filling. Materials (Basel)3(2): $1228-1243$

8. Guzmán H (2003)BiomaterialesOdontológicos de UsoClínico. $\left(3^{\text {rd }} e d n\right)$, Bogota: EcoeEdiciones. Colombia, South America.

9. Ferracan LJ (1995) Materials in Dentistry; Principles and Applications. $\left(2^{\text {nd }} e d n\right)$, JB Lippincott Company, USA.

10. Mustafa RA, Alkhafaji A (2013)Efecto de Los DiferentesSistemas de Acabado y Pulido Sobre la Rugosidad Superficial de Resinas de Baja Polimerización. Rev J Bagh College Dentistry25(4):24-30.

11. Caramori Rodrigues V, Lúcia Schmitt V, Rücker M, Pinceli Chaves L, Pardo SalataNahsan F (2012)Sistemas de Pulido en un o Multiples Pasos de ResinasCompuestasHibridas y suAlteraciónen la Estabilidad del Clor y Rugosidad Superficial. Revista acta OdontológicaVenezolana52(1): 5-8.

12. Fukuhara-Nakama Mary, Quintana-Del Solar Martin, Aguilar-Mendoza Jose (2013) Comparación in Vitro del Efecto del Pulido en la Morfología Superficial de Tres ResinasCompuestas. Rev EstomatolHerediana 23(4): 185-192.

13. Maiara Justo Polli, Guilherme AnzilieroArossi (2015) Effect of Finishing and Polishing on the Color Stability of a Composite Resin Immersed in Staining Solutions 2(3): 120-126.

14. Bittencourt BS (2011)Rugosidad de la Superficie y Susceptibilidad de Tinción de las ResinasCompuestasPulidas con VariosSistemas. Journal OdontologíaEstética y Restaurativa23(1): 34-43.

15. RODRIGUEZ G Douglas R, PEREIRA S Natalie A (2008) Evolución y Tendencia Actual enResinasCompuestas. Acta OdontoLatinoam43(3):10-14.

16. Marigo L, Rizzi M, La Torre G, Rumi G (2001) 3-D Surface Profile Analysis: Different Finishing Methods for Resin Composites. OperDent 26(6): $562-568$. 
17. K William Mopper (2011) Contouring, Finishing, And Polishing Anterior Composites. Inside Dentistry.

18. Henostroza G (2006)EstéticaenOdontologíaRestauradora.(10 $\left.{ }^{\text {th }} \mathrm{edn}\right)$, Ripano S.A.Madrid, Spain.

19. BorgesBA(2004)RugosidadSuperficialdeResinasCondensablesPulidas con VariosSistemas. Journal OdontologiaEstética y Restaurativa16(1):42-47.

20. Javier Martín, Gustavo Moncada, Francisco Serey, Alejandro Oyarzún, Pablo Angel, et al. (2009)Efecto de Cinco Sistemas de Pulido de
ResinasCompuestasSobreSuperficieCoronaria y Radicular. Revista acta Odontológicavenezolana.

21. Rodriguez AR, Peris GS (2004) Sistema de Acabado y Pulido de ResinasCompuestas: AnalisisPerfilometrico. Oper Dent22: 98-104.

22. Perfil Técnico Del Producto (2010)Optrapol®. IvoclarVivadentAG. Switzerland.

23. Perfil Técnico Del Producto Enhance $®(2007)$ Dentsply. USA.

24. Perfil Técnico Del ProductoSof-Lex ${ }^{\mathrm{TM}}(2000) 3 \mathrm{M}$ ESPE. USA.

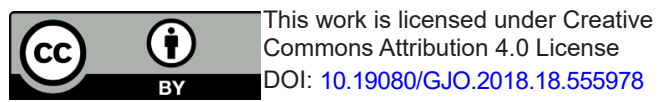

\section{Your next submission with Juniper Publishers will reach you the below assets}

- Quality Editorial service

- Swift Peer Review

- Reprints availability

- E-prints Service

- Manuscript Podcast for convenient understanding

- Global attainment for your research

- Manuscript accessibility in different formats

( Pdf, E-pub, Full Text, Audio)

- Unceasing customer service

Track the below URL for one-step submission https://juniperpublishers.com/online-submission.php 